\title{
Indole-3-acetic acid production by Streptomyces fradiae NKZ-259 and its formulation to enhance plant growth
}

\author{
Ei Mon Myo ${ }^{1,2 \dagger}$, Beibei Ge ${ }^{1+}$, Jinjin Ma ${ }^{1}$, Hailan Cui', Binghua Liu', Liming Shi', Mingguo Jiang ${ }^{3}$ and \\ Kecheng Zhang ${ }^{1 *}$ (D)
}

\begin{abstract}
Background: Indole-3-acetic acid (IAA) is produced by microorganisms and plants via either tryptophan-dependent or tryptophan-independent pathways. Herein, we investigated the optimisation of IAA production by Streptomyces fradiae NKZ-259 and its formulation as a plant growth promoter to improve economic and agricultural development.

Results: The maximum IAA yield achieved using optimal conditions was $82.363 \mu \mathrm{g} / \mathrm{mL}$ in the presence of $2 \mathrm{~g} / \mathrm{L}$ tryptophan after 6 days of incubation. Thin-layer chromatography (TLC) and high-performance liquid chromatography (HPLC) analysis of putative IAA revealed an RF value of 0.69 and a retention time of $11.842 \mathrm{~min}$, comparable with the IAA standard. Regarding product formulation, kaolin-based powder achieved a suspension rate of $73.74 \%$ and a wetting time of $80 \mathrm{~s}$. This carrier exhibited good shelf life stability for NKZ-259, and the cell population did not decrease obviously over 4 months of storage at $4{ }^{\circ} \mathrm{C}$. In vivo analysis of plant growth promotion showed that tomato seedlings treated with kaolin powder containing NKZ-259 cells displayed a significant increase in root and shoot length of $7.97 \mathrm{~cm}$ and $32.77 \mathrm{~cm}$, respectively, and an increase in fresh weight and dry weight of $6.72 \mathrm{~g}$ and $1.34 \mathrm{~g}$. Compared to controls, plant growth parameters were increased almost it two-fold.

Conclusion: Optimising the culture conditions resulted in an almost four-fold increase in IAA secretion by NKZ-259 cells. The results clearly demonstrate that $S$. fradiae NKZ-259 holds great potential for plant growth promotion and IAA production. Furthermore, kaolin-based powder is an effective carrier for NKZ-259 cells and may be useful for commercial applications.
\end{abstract}

Keywords: Indole-3-acetic acid, Optimal conditions, TLC, HPLC, Formulation, Plant growth promotion

\section{Background}

Actinomycetes are Gram-positive, plant growth-promoting rhizobacteria that promote plant growth either directly or indirectly [1]. These microbes secrete antibiotics, vitamins and enzymes [2] including indole-3-acetic acid (IAA) [3] and play a key role in the decomposition of organic matter [4] and phosphorus solubilisation [5]. IAA is a common natural auxin phytohormone with an indole ring [6] and a product of L-tryptophan metabolism in microorganisms [7]. Various genera of

\footnotetext{
* Correspondence: zhangkecheng@sina.com

${ }^{+}$Ei Mon Myo and Beibei Ge contributed equally to this work.

'State Key Laboratory of Biology of Plant Diseases and Insect Pests, Institute of Plant Protection, Chinese Academy of Agricultural Sciences, Beijing, China Full list of author information is available at the end of the article
}

plant growth-promoting bacteria including actinomycetes and fungi improve plant growth via IAA production through L-tryptophan-dependent mechanisms [6]. Some studies revealed that among IAA-producing actinomycetes, Streptomyces sp. is the dominant genus for IAA production [8]. IAA plays a role in a plethora of plant developmental and physiological processes, including embryogenesis, organogenesis, vascular differentiation, root and shoot development, trophic growth, and fruit development [9]. However, the ability of Streptomyces cultures to form these bioactive products is not a fixed property, and can be greatly increased or completely lost under different nutrition and cultivation conditions. This is because antibiotic

(C) The Author(s). 2019 Open Access This article is distributed under the terms of the Creative Commons Attribution 4.0 International License (http://creativecommons.org/licenses/by/4.0/), which permits unrestricted use, distribution, and 
biosynthesis is a specific property of microorganisms that is strongly dependent on the culture conditions. Cell growth and antibiotic production can be improved by manipulating culture nutritional and physical parameters. Thus, media composition plays a vital in terms of efficiency and cost. Carbohydrates and nitrogen play key roles as structural and energy compounds in the cell. Numerous cultivation parameters including $\mathrm{pH}$, carbon source, nitrogen source, and L-tryptophan supplementation can affect bacterial growth and IAA yield. Therefore, designing an appropriate fermentation medium is of critical importance in the production of secondary metabolites [10].

Optimisation of fermentation parameters is imperative for maximising the yield in large-scale microbial production, and parameters that improve outputs must be ascertained [11]. The traditional one-factor-at-a-time (OFAT) approach for optimisation can be timeconsuming. Nonetheless, it can estimate optimum levels of medium constituents [12, 13]. Problems that diminish yields can be identified and addressed using statistical tools. For example, a Plackett-Burman experimental design and response surface methodology (RSM) analysis using central composite and BoxBehnken designs has been applied to optimise fermentation parameters $[14,15]$. In comparison with conventional optimisation methods in which one variable is varied at a time, RSM has several advantages. It provides a wealth of information and is a more economical approach because a small number of experiments are performed to monitor the effects of interactions between independent variables on the response. Traditional optimisation takes a long time to carry out and leads to an increase in cost due to the large number of experiments needed and the quantities of reagents and materials required [16]. Another disadvantage of experimental optimisation using classical methods that change one factor at a time and fix all other factors is that it does not consider the effects of interactions between different factors under study. Rhizosphere actinomycetes have been studied and developed as commercial products using such methods [17].

Since it is not usually convenient to use freshly prepared inocula in the field, biocontrol/plant growthpromoting (PGP) agents have been developed as powders, solids, and liquid formulations that are more suitable for storage, transportation, and application on a commercial scale [18]. Many PGP rhizobacteria (PGPR) have been formulated in liquids, solids, and powders for use as bioherbicides and biofertilisers. Dry formulations (granules or powders) are generally preferred over liquids due to a longer shelf-life and facile transportation and storage. Furthermore, most granular and powder formulations can also be made into liquids and water- based suspensions as required for drenching, spraying and root-dipping applications [19].

Streptomyces fradiae NKZ-259 possesses marked antifungal activity against various plant pathogenic fungi including Botrytis cinerea, Curvularia lunata, Alternaria alternata, Colletotrichum gloeosporioides, Rhizoctonia cerealis and Ustilaginoidea virens [20]. The present study focused on optimising the parameters affecting IAA production by $S$. fradiae NKZ-259 and assessing formulation for commercial applications. Various studies have attempted to optimise IAA production by microbes. However, few have applied the response surface methodology (RSM) approach. To our knowledge, this is the first study to apply RSM for the optimisation of IAA production by Streptomyces.

\section{Results}

Optimisation of culture conditions for maximising IAA production using the one-factor-at-a-time (OFAT) method Under optimal conditions, NKZ-259 cells exhibited a maximum growth rate on the ninth day of incubation, peaking at $0.25 \mathrm{~g} / 10 \mathrm{~mL}$ of dry weight. However, on the following day the cell density decreased to $0.02 \mathrm{~g} / 10 \mathrm{~mL}$, and the density continued to decrease until the final sampling time after 2 weeks of incubation. During this time, the $\mathrm{pH}$ of the fermentation broth decreased from 6.5 to 6 , which was not significant.

OFAT optimisation experiments showed that the highest IAA production under optimal medium and culture conditions was $20.46 \mu \mathrm{g} / \mathrm{mL}$ using Gause's No.1 medium in the presence of $2 \mathrm{~g} / \mathrm{L}$ tryptophan, hence this was used in subsequent experiments. Under these conditions, the IAA concentration reached $4.16 \mu \mathrm{g} / \mathrm{mL}$ in ISP-1, $5.75 \mu \mathrm{g} / \mathrm{mL}$ in ISP-2, 0.80 in ISP-3, $8.10 \mu \mathrm{g} / \mathrm{mL}$ in ISP-4, $3.94 \mu \mathrm{g} / \mathrm{mL}$ in Bennet medium, $4.65 \mu \mathrm{g} / \mathrm{mL}$ in $\mathrm{MS}$ medium, $5.44 \mu \mathrm{g} / \mathrm{mL}$ in Streptomyces medium and $2.79 \mu \mathrm{g} / \mathrm{mL}$ in Tryptic soy agar. NKZ-259 reached maximal growth rate on the ninth day of incubation, suggesting that secondary metabolite production in this strain was not directly correlated with cell growth.

The IAA productivity of NKZ-259 was studied for 2 weeks, and day $6(144 \mathrm{~h})$ was found to be the time of maximum production. On the first day of incubation, only $6.442 \mu \mathrm{g} / \mathrm{mL}$ of IAA was secreted by this strain, but this increased gradually over the following days, peaking at $24.027 \mu \mathrm{g} / \mathrm{mL}$ after 6 days. Changes in cell mass, $\mathrm{pH}$ and IAA production for NKZ-259 over the 2 week incubation are illustrated in Fig. 1.

NKZ-259 achieved a maximum yield of $42.345 \mu \mathrm{g} / \mathrm{mL}$ IAA in the presence of starch and $\mathrm{KNO}_{3}$, the major substrates in Gause's No.1 medium. Conversely, IAA production was minimal when sorbitol and casein were added to the medium, reaching only $15.31 \mu \mathrm{g} / \mathrm{ml}$ and $11.771 \mu \mathrm{g} / \mathrm{mL}$, respectively. This strain produced only a 


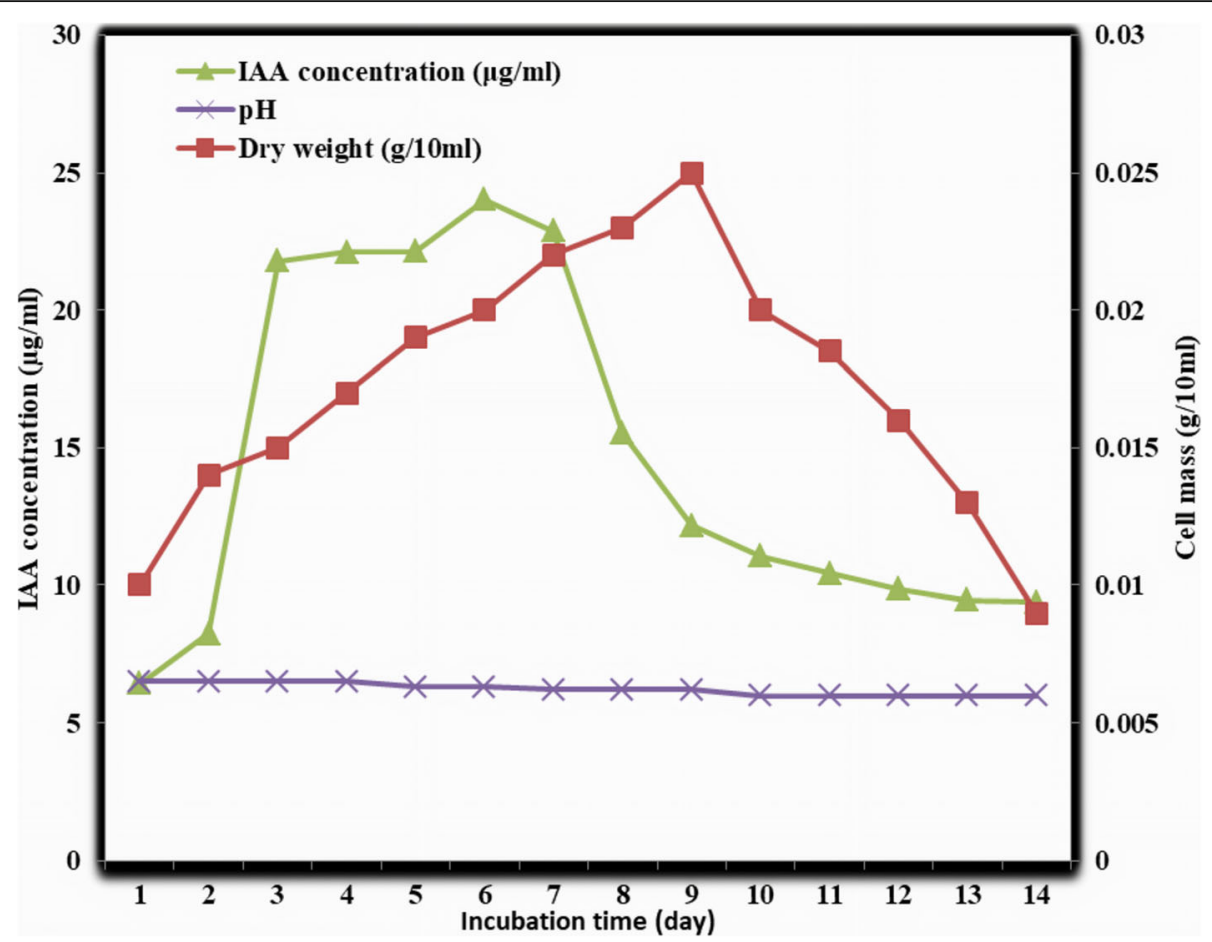

Fig. 1 Growth rate and IAA production of NKZ-259 over a period of 2 weeks with respect to pH

small amount of IAA when carbon and nitrogen sources were omitted from the fermentation medium, demonstrating that these macronutrients had a dramatic effect on PGP hormone production in NKZ-259.

Supplementation of $2 \mathrm{~g} / \mathrm{L}$ tryptophan in the medium was optimum for IAA production, and NKZ-259 cells secreted up to $56.283 \mu \mathrm{g} / \mathrm{mL}$ IAA. When tryptophan supplementation was increased to $10 \mathrm{~g} / \mathrm{L}$, IAA production was only $40.22 \mu \mathrm{g} / \mathrm{mL}$, and a higher tryptophan concentration had an adverse effect on the IAA production capacity of this potent PGP strain. However, NKZ259 could produce only $4.876 \mu \mathrm{g} / \mathrm{mL}$ IAA without tryptophan in the medium.

\section{Optimisation using Plackett-Burman experiments}

The Plackett-Burman design (PBD) was applied to examine the fermentation medium factors having the greatest effect on IAA production. Eight potentially important variables (starch, $\mathrm{KNO}_{3}, \mathrm{NaCl}, \mathrm{K}_{2} \mathrm{HPO}_{4}, \mathrm{MgSO}_{4}, \mathrm{FeSO}_{4}$, tryptophan and incubation time) were identified by the OFAT method and statistically optimised using the PBD approach. The actual values of each factor and details of the design experiment are shown in (Additional file 1) and (Additional file 2). The results showed that $(\mathrm{g} / \mathrm{L}) \mathrm{X} 1$ (starch)-15, X2 ( $\left.\mathrm{KNO}_{3}\right)-1.5, \mathrm{X} 3(\mathrm{NaCl})-0.4, \mathrm{X} 4 \quad\left(\mathrm{FeSO}_{4}\right)-$ 0.005, X5 ( $\left.\mathrm{MgSO}_{4}\right)-0.4, \mathrm{X} 6\left(\mathrm{~K}_{2} \mathrm{HPO}_{4}\right)-0.6, \mathrm{X} 7$ (tryptophan)-3 and $\mathrm{X} 8$ (incubation time)-7 were the optimum values for IAA production, which reached $52.058 \mu \mathrm{g} / \mathrm{mL}$. Only $27.186 \mu \mathrm{g} / \mathrm{mL}$ IAA was secreted when the composition of the medium was $(\mathrm{g} / \mathrm{L}) \mathrm{X} 1-15, \mathrm{X} 2-1.5$, X3-0.6, X4-0.005, X5-0.6, X6-0.4, X7-1 and X8-5. Statistical analysis of the PBD approach clearly indicated that soluble starch, $\mathrm{KNO}_{3}, \mathrm{NaCl}, \mathrm{K}_{2} \mathrm{HPO}_{4}$, tryptophan and incubation time were the most significant parameters among the eight variables (Table 1). One-way analysis of variance (ANOVA) showed that $p$-values for soluble starch, $\mathrm{KNO}_{3}, \mathrm{NaCl}, \mathrm{K}_{2} \mathrm{HPO}_{4}$, tryptophan and incubation time were significant $(0.020,0.037,0.004,0.003,0.000$ and 0.014 , respectively), whereas $p$-values for $\mathrm{FeSO}_{4}$ and $\mathrm{MgSO}_{4}$ were not significant, hence these constituents were omitted in the subsequent RSM analysis. The

Table 1 Statistical analysis of the Plackett-Burman design for IAA production by Streptomyces fradiae NKZ-259

\begin{tabular}{lllll}
\hline Variable/Term & Coefficient & SE coefficient & t-value & $p$-value \\
\hline Constant & 37.923 & 0.481 & 78.77 & 0.000 \\
X1 & 2.198 & 0.481 & 4.56 & $0.020^{*}$ \\
X2 & 1.731 & 0.481 & 3.60 & $0.037^{*}$ \\
X3 & -4.055 & 0.481 & -8.42 & $0.004^{*}$ \\
X4 & -1.453 & 0.481 & -3.02 & 0.057 \\
X5 & 0.729 & 0.481 & 1.51 & 0.227 \\
X6 & 4.142 & 0.481 & 8.60 & $0.003^{*}$ \\
X7 & 7.864 & 0.481 & 16.33 & $0.000^{*}$ \\
X8 & -2.479 & 0.481 & -5.15 & $0.014^{*}$ \\
\hline
\end{tabular}

R-sq $=99.38 \%$ R-sq (adj) $=97.74 \%$

$\mathrm{SE}$, standard error; t, Student's test; $p$, corresponding level of significance; ${ }^{*}$, significance at $p<0.05$ 
variance of the actual response was clarified using $R^{2}$ values to check the correctness and fitness of the model, and $R^{2}$ values could explain $99.38 \%$ of the variation in the data (i.e. only $0.62 \%$ was not accounted for by the model). The smaller the R-squared value, the less capable the model is for clarifying the variation in dependent variables. The regression equation in uncoded units for this design was as follows:

IAA $(\mu \mathrm{g} / \mathrm{mL})=23.64+0.4395 \quad \mathrm{X} 1+3.462 \quad \mathrm{X} 2-$ 40.55 X3 - 290.6 X4+7.29 X5 + 41.43 X6 + 7.864 X7 $2.479 \mathrm{X} 8$. The factors having the greatest effect on IAA production are summarised in the Pareto chart [21] in Fig. 2.

\section{Optimisation of process variables by response surface methodology (RSM) analysis}

The Box-Behnken design was used to further optimise the six factors identified as significant using PBD analysis. The actual values of the process variables are listed in (Additional file 3), and the matrix design and actual response values for IAA productivity are shown in (Additional file 4). In this design, run 40 comprising ( $\mathrm{g} / \mathrm{L}$ ) A (starch)-20, B ( $\left.\mathrm{KNO}_{3}\right)-1, \mathrm{C}(\mathrm{NaCl})-0.5, \mathrm{D}\left(\mathrm{K}_{2} \mathrm{HPO}_{4}\right)-0.4$, $\mathrm{E}$ (tryptophan)-2 and $\mathrm{F}$ (incubation time)- 6 was optimum for IAA production, which reached $82.363 \mu \mathrm{g} / \mathrm{mL}$. The lowest IAA yield of $22.288 \mu \mathrm{g} / \mathrm{mL}$ was secreted when the composition was (g/L) A-20, B-0.5, C-0.6, D-0.5, E-3, and F-6. Table 2 summarises the results of ANOVA. The very low $p$-value $(p<0.0001)$ suggests that the model fits the experimental data very well, and the Model F-value of 9.26 also indicates high model accuracy. In this case, model terms $\mathrm{A}, \mathrm{B}, \mathrm{C}, \mathrm{F}, \mathrm{DF}, \mathrm{A}^{2}, \mathrm{~B}^{2}, \mathrm{C}^{2}, \mathrm{E}^{2}$ and $\mathrm{F}^{2}$ were significant, while values greater than 0.1000 were not significant. An F-value for the Lack of Fit of 1.52 demonstrated that it was not significant, suggesting model fitting was good, with only a $34.30 \%$ chance that it could be due to noise. A Pred R-squared value of 0.5471 was in accordance with an Adj R-squared value of 0.6858 , and the ANOVA equation describing the predicted response was as follows:

$$
\begin{aligned}
\mathrm{Y}(\text { predicted response })= & 73.89+5.71 * \mathrm{~A}+5.93 * \mathrm{~B} \\
& +4.76 * \mathrm{C}-3.39 * \mathrm{D}-2.12 \\
& * \mathrm{E}+7.42 * \mathrm{~F}+7.38 * \mathrm{~A} \\
& * \mathrm{C}-6.61 * \mathrm{~A} * \mathrm{E}-10.82 * \mathrm{D} \\
& * \mathrm{~F}-12.81 * \mathrm{~A} 2-14.71 \\
& * \mathrm{~B} 2-12.23 * \mathrm{C} 2-17.08 \\
& * \mathrm{E} 28.67 * \mathrm{~F} 2
\end{aligned}
$$

Relationships between significant variables and optimal values for each factor affecting IAA production were assessed using response surface plots [22]. Using the approach, the effects of the two components are considered while those of other variables are kept at zero. Figure 3 shows the relationships between each pair of variables and maximum IAA production by NKZ-259.

IAA confirmation by thin-layer chromatography (TLC) and high-performance liquid chromatography (HPLC)

As shown in Fig. 4, spots separated on TLC plates were developed and observed under UV light at $245 \mathrm{~nm}$. The

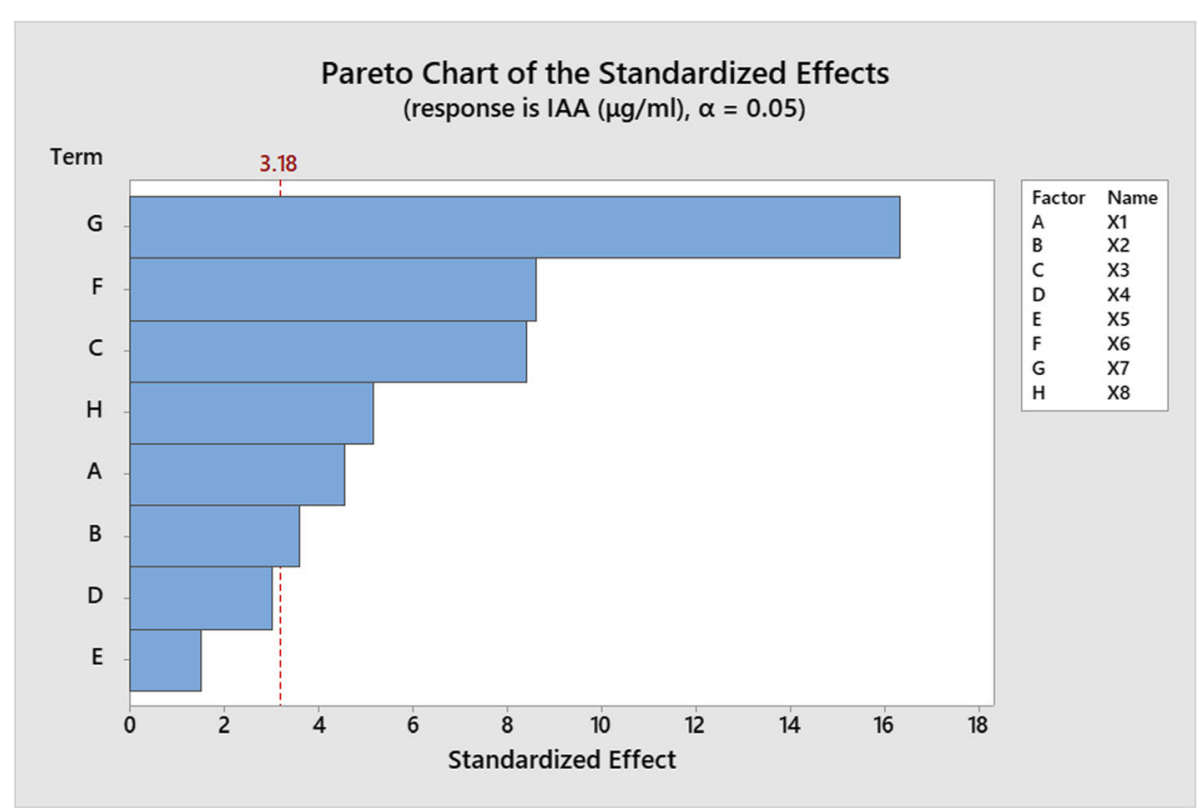

Fig. 2 Pareto chart of the standardised effects of different parameters of the plant growth-promoting ability of Streptomyces fradiae NKZ-259 
Table 2 Statistical analysis of the Box-Behnken design

\begin{tabular}{|c|c|c|c|c|c|}
\hline Source & Sum of squares & Degree of freedom & Mean square & F-value & $p$-value (prob $>F$ \\
\hline Model & $14,220.13$ & 14 & 1015.72 & 9.26 & $<0.0001$ \\
\hline A-Starch & 781.77 & 1 & 781.77 & 7.13 & 0.0110 \\
\hline $\mathrm{B}-\mathrm{KNO}_{3}$ & 842.58 & 1 & 842.58 & 7.69 & 0.0085 \\
\hline $\mathrm{C}-\mathrm{NaCl}$ & 542.72 & 1 & 542.72 & 4.95 & 0.0319 \\
\hline $\mathrm{D}-\mathrm{K}_{2} \mathrm{HPO}_{4}$ & 276.29 & 1 & 276.29 & 2.52 & 0.1205 \\
\hline E-Tryptophan & 108.14 & 1 & 108.14 & 0.99 & 0.3268 \\
\hline F-Incubation time & 1320.17 & 1 & 1320.17 & 12.04 & 0.0013 \\
\hline$A C$ & 435.48 & 1 & 435.48 & 3.97 & 0.0533 \\
\hline$A E$ & 349.03 & 1 & 349.03 & 3.18 & 0.0822 \\
\hline DF & 936.62 & 1 & 936.62 & 8.54 & 0.0057 \\
\hline$A^{2}$ & 1836.64 & 1 & 1836.64 & 16.75 & 0.0002 \\
\hline$B^{2}$ & 2273.38 & 1 & 2273.38 & 20.74 & $<0.0001$ \\
\hline$C^{2}$ & 1569.56 & 1 & 1569.56 & 14.32 & 0.0005 \\
\hline$E^{2}$ & 3062.90 & 1 & 3062.90 & 27.94 & $<0.0001$ \\
\hline$F^{2}$ & 789.01 & 1 & 789.01 & 7.20 & 0.0107 \\
\hline Residual & 4275.65 & 39 & 109.63 & & \\
\hline Lack of Fit & 3898.03 & 34 & 114.65 & 1.52 & 0.3430 \\
\hline Pure Error & 377.63 & 5 & 75.53 & & \\
\hline
\end{tabular}

$R^{2}=0.7688 ;$ Adj $R^{2}=0.6858 ;$ Pred R-squared $=0.5471$

results revealed that a standard IAA sample and putative IAA samples extracted from NKZ-259 cells displayed the same retention factor (RF) value of 0.69 . Similarly, the HPLC elution profile of an authentic IAA standard exhibited a major peak at a retention time of $11.852 \mathrm{~min}$, while IAA isolated from NKZ-259 appeared as a sharp peak at a similar retention time of $11.842 \mathrm{~min}$ (Fig. 5).

\section{Germination rate and plant growth promotion by NKZ- 259 under greenhouse conditions}

In germination assessment, all treatments exhibited $100 \%$ germination rates on tomato seeds (Table 3 ). The effects of NKZ-259 on plant growth promotion, including root development, were assessed. Root elongation assays and pot experiments were performed using tomato seeds inoculated with the PGP NKZ-259 strain. Water, medium, cell-free filtrate and culture treatments were significantly different from each other. In plant growth promotion assays, NKZ-259 cultures significantly enhanced plant growth by increasing the root length, shoot length, fresh weight and dry weight of all plants. After 5 weeks of growth, NKZ-259 cells promoted root length to $8.08 \mathrm{~cm}$, shoot length to $24.20 \mathrm{~cm}$, fresh weight to $2.63 \mathrm{~g}$ and dry weight to $0.25 \mathrm{~g}$. In filtrate-treated plants, root and shoot length were enhanced by $7.50 \mathrm{~cm}$ and $23.13 \mathrm{~cm}$, respectively, while fresh weight and dry weight were increased to $2.56 \mathrm{~g}$ and $0.24 \mathrm{~g}$, respectively. These plant growth parameters were not significantly different from the other two treatments. Table 4 summarises the plant growth-promoting effects of this potent strain on tomato plants.

\section{In vivo analysis of plant growth promotion by the formulated products}

The effects of each treatment on plant growth were determined at 35 days after planting. Tomato plants treated with each product indicated better PGP effects than control treatments. Among the different formulations, tomato plants treated with NKZ-259 formulated with kaolin-based powder displayed increased shoot length $(32.77 \mathrm{~cm})$, root length $(7.97 \mathrm{~cm})$, fresh weight $(6.72 \mathrm{~g})$ and dry weight $(1.34$ g) (Fig. 6 and Table 5). This was the only parameter that showed a statistically significant correlation with plant growth promotion. Among the different treatments, minimum plant growth was mediated by water alone.

\section{Suspension rate and wetting time of carriers}

In our current experiments, the suspension rate of kaolin-based powder was better than that of talc powder, which also displayed a longer wetting time, resulting in very slow suspension in water. By contrast, kaolin powder achieved both a higher suspension rate and better wettability. Table 6 summarises $\mathrm{pH}$, suspension rate and wettability for each representative powder.

\section{Shelf life analysis}

The density of NKZ-259 cells was $5.6 \times 10^{6}$ colony-forming units $(\mathrm{CFU}) / \mathrm{ml}$ in each formulated product, and the cell 


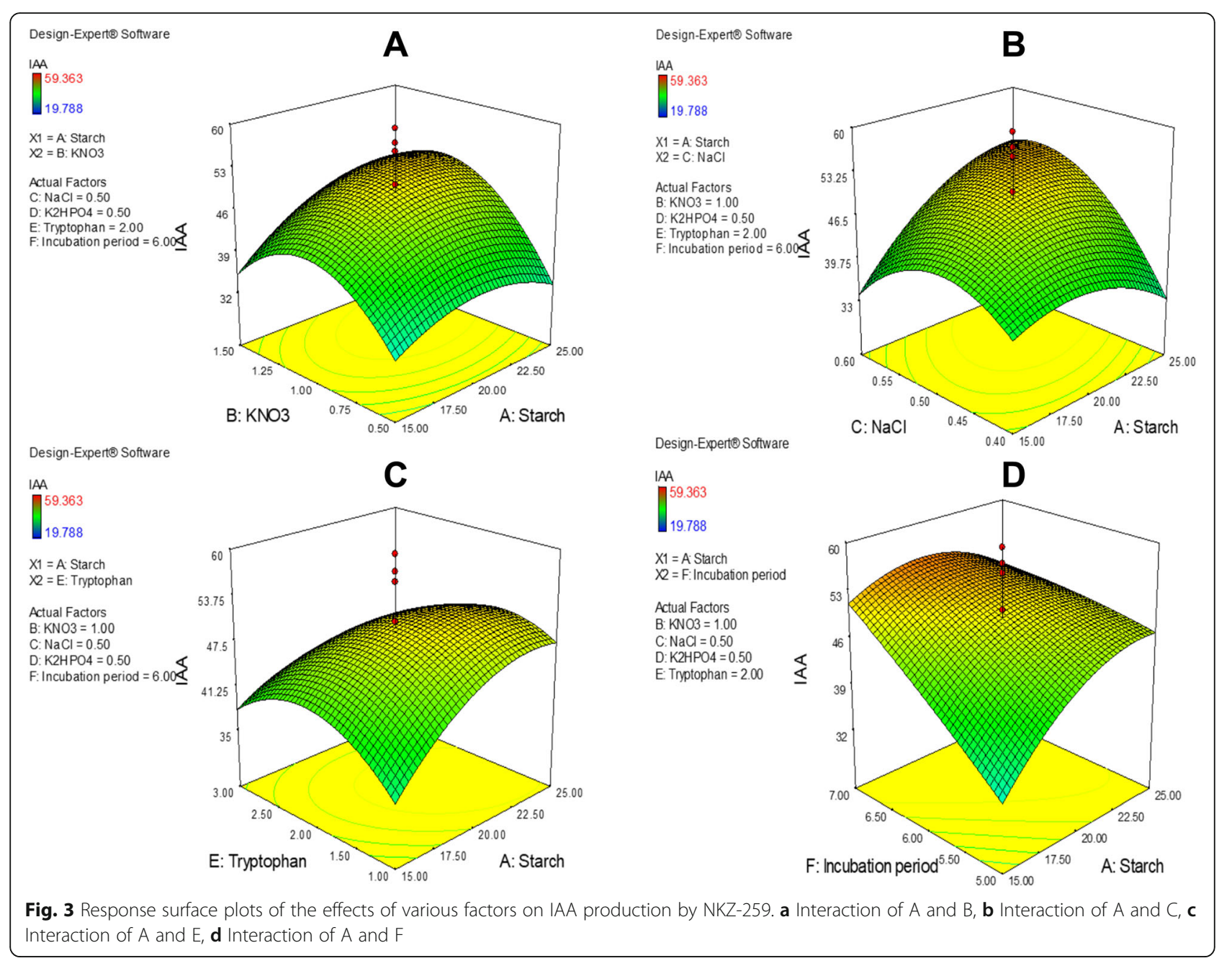

count in each carrier was determined at 1-month intervals over 3 months by the serial dilution plate count method. After 1 month of storage at $4{ }^{\circ} \mathrm{C}$, the population of cells in kaolin powder was stable, and the population was almost stable after storage at room temperature. However, the population of NKZ-259 cells in talc and liquid carriers was slightly decreased during storage at both $4{ }^{\circ} \mathrm{C}$ and room temperature. After 2 months of storage, the population of cells had declined gradually, but the decrease was slight and not significant in kaolin powder. After 2 months of storage, although the cell populations in kaolin powder kept in a refrigerator or at room temperature were nearly stable at $5.2 \times 10^{6} \mathrm{CFU} / \mathrm{mL}$ and $2.3 \times 10^{6} \mathrm{CFU} / \mathrm{mL}$, respectively, the cell density in talc-based powder kept at $4{ }^{\circ} \mathrm{C}$ or room temperature was reduced to $6.5 \times 10^{4} \mathrm{CFU} / \mathrm{mL}$ and $5.5 \times$ $10^{4} \mathrm{CFU} / \mathrm{mL}$, respectively, compared with $1.0 \times 10^{4} \mathrm{CFU} /$ $\mathrm{mL}$ in the liquid carrier. The cell density in kaolin powder for both storage conditions remained constant up to 3 months of storage, whereas cells in talc powder decreased slightly to $5.8 \times 10^{4} \mathrm{CFU} / \mathrm{mL}$ and $4.8 \times 10^{4} \mathrm{CFU} / \mathrm{mL}$ at $4{ }^{\circ} \mathrm{C}$ and room temperature, respectively. However, the NKZ-
259 population in the liquid carrier decreased to $1.0 \times 10^{3}$ $\mathrm{CFU} / \mathrm{mL}$ at both storage temperatures. At the final sampling time (4 months of storage), the number of NKZ-259 cells in kaolin powder had decreased slightly but not significantly. At this time point, the population in talcbased powder had declined to $3.9 \times 10^{4} \mathrm{CFU} / \mathrm{mL}$ and $2.0 \times$ $10^{4} \mathrm{CFU} / \mathrm{mL}$ at $4{ }^{\circ} \mathrm{C}$ and room temperature, respectively. Additionally, the number of cells in the liquid carrier had decreased significantly to $\sim 0.5 \times 10^{3} \mathrm{CFU} / \mathrm{mL}$ at $4{ }^{\circ} \mathrm{C}$ and $\sim 0.2 \times 10^{3} \mathrm{CFU} / \mathrm{mL}$ at room temperature. Powder formulations kept at $4{ }^{\circ} \mathrm{C}$ displayed a longer shelf life than samples stored at room temperature. Among the three formulations, kaolin-based powder was the most suitable carrier for NKZ-259 stability; even after 4 months, the cell population at $4{ }^{\circ} \mathrm{C}$ was not obviously decreased (Table 7).

\section{Discussion}

The statistical optimisation method has been applied to IAA production, but statistical optimisation of medium components for IAA production by Streptomyces fradiae 


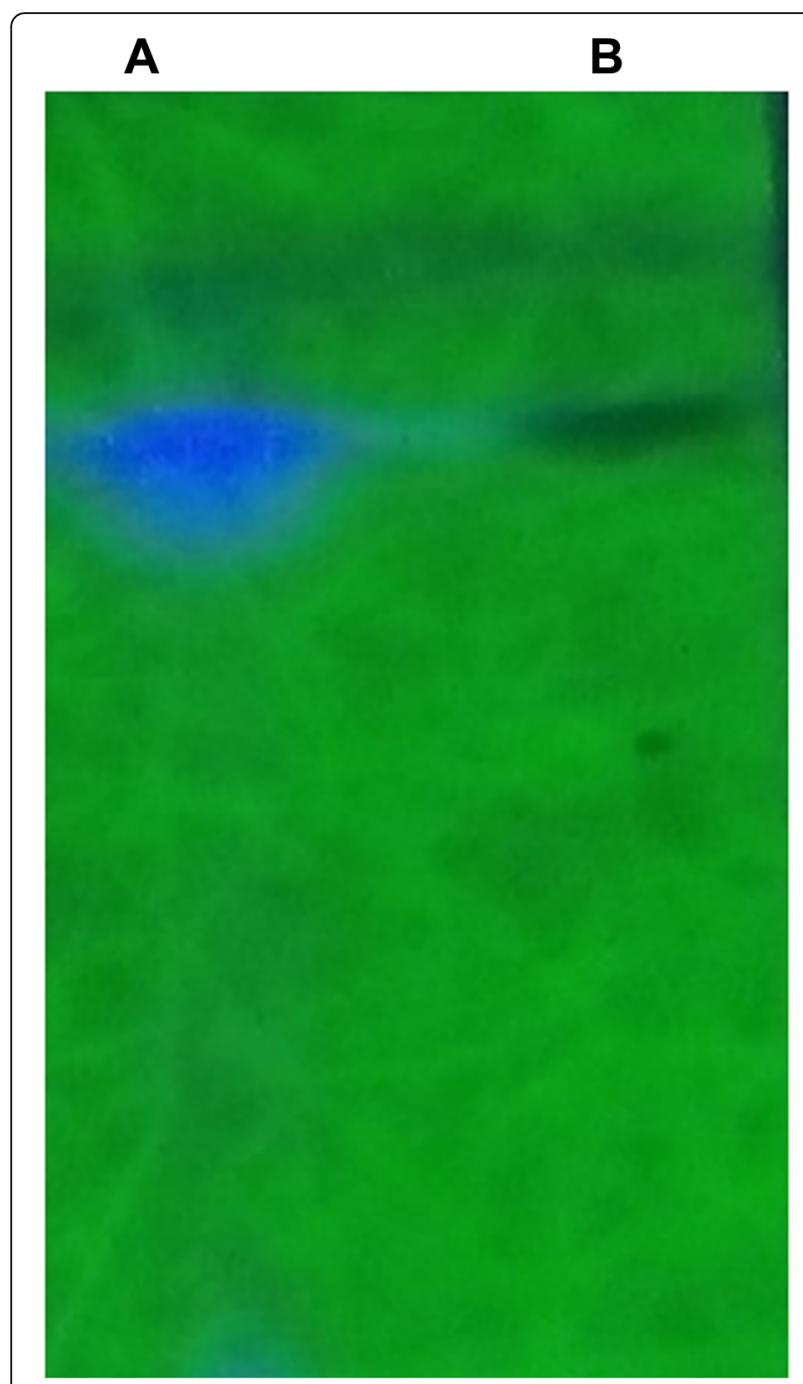

Fig. 4 Confirmation of IAA production by NKZ-259 using thin-layer chromatography (TLC). a extracted IAA; b standard IAA

based on statistical design is yet to be reported. Streptomyces species typically require organic carbon and inorganic nitrogen sources plus mineral salts for growth as well as secondary metabolite production [23]. The IAA-producing activity of PGPR varies among species and is greatly influenced by culture conditions, growth stage and substrate ability [24]. Optimisation of the fermentation medium is imperative for maximising the ability of microbes to produce secondary metabolites on an industrial scale. Although carbon nutrients are essential, nitrogen sources and other micronutrients should not be neglected when optimising production [25].

The results of OFAT experiments showed that in addition to nutrients in the fermentation medium, tryptophan and incubation time played an important role in
IAA production by NKZ-259; IAA production was improved from $4.876 \mu \mathrm{g} / \mathrm{mL}$ IAA in the absence of tryptophan to $56.28 \mu \mathrm{g} / \mathrm{ml}$ in its presence, strongly indicating that tryptophan is a precursor for IAA production. Furthermore, NKZ-259 appears to secrete IAA via a tryptophan-dependent biosynthetic pathway. This finding is consistent with the knowledge that actinomycetes possess the ability to produce the auxin phytohormone IAA in the presence of a suitable precursor such as Ltryptophan [26]. However, other pathways may be included in this mechanism because some bacteria possess more than one pathway [27].

Following OFAT optimisation, we optimised the fermentation medium, tryptophan supplementation, and incubation time using the Plackett-Burman design (PBD) and Box-Behnken design. NKZ-259 produced only $20.46 \mu \mathrm{g} / \mathrm{mL}$ IAA in the original fermentation medium in the presence of tryptophan, but the yield was increased to $82.363 \mu \mathrm{g} / \mathrm{mL}$ after this round of optimisation, equating to a four-fold increase in IAA produced. These findings are consistent with previous reports demonstrating the advantages of the RSM approach [28].

TLC analysis of IAA standards and extracted samples revealed identical $\mathrm{Rf}$ values, consistent with previous studies [29]. HPLC is a more reliable and powerful method for identifying and analysing auxins than mass spectrometry [30]. Thus, we characterised IAA extracted from NKZ-259 by HPLC. The retention times of sample peaks were comparable to those of authentic IAA standards, confirming that strain NKZ-259 produced IAA and was indeed a PGPR member.

In vivo plant growth promotion assays showed that plants treated with kaolin powder containing NKZ259 exhibited the highest root and shoot lengths, as well as fresh and dry weights. Although plants treated with T2 (kaolin powder without bacteria), T3 (talc powder without bacteria), T4 (molasses and humic acid without bacteria) displayed increased root elongation superior to that of plants treated with T1 (water), other characteristics were inferior to those of T1-treated plants. Plants treated with carriers containing NKZ-259 displayed significantly increased growth, and those treated only with kaolin and talc-based powders did not exhibit significant plant growth promotion. Thus, the NKZ-259 strain early promoted plant growth, which may be due to metabolites produced by NKZ-259 other than IAA. However, at nearly every developmental stage (embryonic and postembryonic) and in every growth process (formation of lateral organs and growth of leaves), plants were affected by IAA directly or indirectly via secondary induced signalling molecules [31]. IAA compounds produced by NKA-259 played an essential role in plant growth promotion because the main 


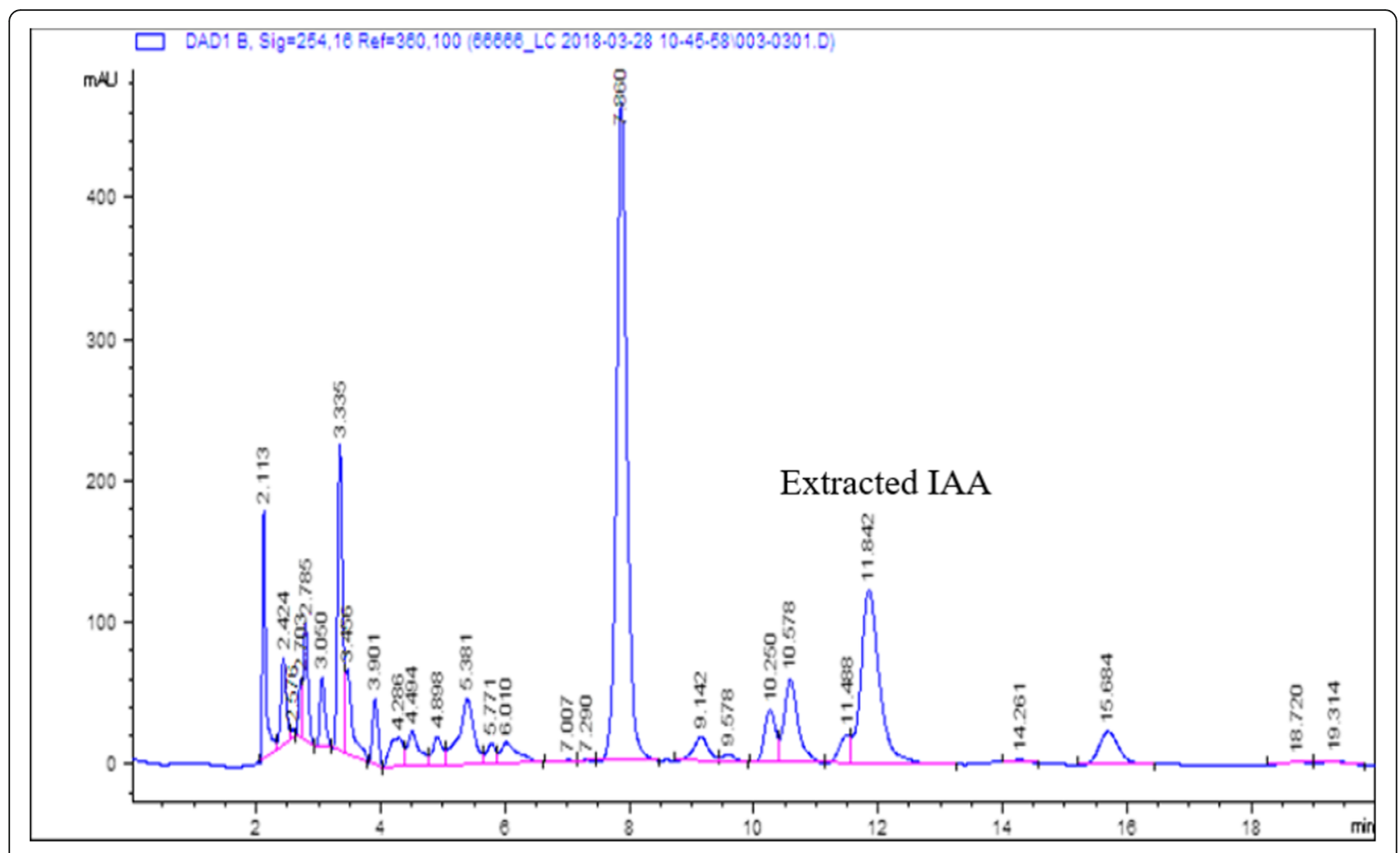

Fig. 5 Analysis of IAA production by NKZ-259 using high-performance liquid chromatography (HPLC)

function of auxins is to stimulate root elongation, and this improvement was obvious in NKZ-259 treated plants.

The national standard for the suspension rate of a wettable powder is $\geq 60 \%$ and the standard wetting time is $\leq 120$ s [32]. Our results show that the kaolin-based product meets these criteria because the suspension rate was $73.74 \%$ and the wettability was $80 \mathrm{~s}$. Furthermore, shelf life analysis showed that the longevity (stability) of NKZ-259 was highest in kaolin powder. This PGP strain was $100 \%$ stable after storage for 1 month, and almost completely stable up to 2 months, and stability was only slightly decreased after 3 months of storage. At the final sampling time (4 months), there was no significant decrease in the NKZ-259 cell population in kaolin powder, whereas a significant decline was observed with the other two carriers. The stability and viability of bacteria in formulations during storage may be influenced by the nutritional supplements added [33]. Our results suggest that the type of carrier in the formulation may affect cell viability. Kaolin-based powder appears to be the most suitable carrier for NKZ-259 formulations intended for agricultural use.

\section{Conclusions}

In this work, we optimised IAA production by NKZ259 using an RSM approach to explore formulations best suited for commercial use in agriculture. A suitable medium for improved IAA production was successfully established, and IAA production was elevated by optimising the culture conditions using a statistical design method. In greenhouse assays, both NKZ-259 and the formulated carrier containing NKZ259 cells could promote growth of tomato plants.

Table 3 Germination tests on tomato plants subjected to representative treatments

\begin{tabular}{llll}
\hline Treatment & Germination (\%) & Root length (cm/seedling) & Shoot length (cm/seedling) \\
\hline Distilled water & $100 \mathrm{a}$ & $4.88 \pm 0.0265 \mathrm{~b}$ & $3.25 \pm 0.0500 \mathrm{c}$ \\
Gause's medium & $100 \mathrm{a}$ & $4.92 \pm 0.0361 \mathrm{~b}$ & $4.52 \pm 0.0436 \mathrm{~b}$ \\
NKZ-259 cells & $100 \mathrm{a}$ & $5.48 \pm 0.0764 \mathrm{a}$ & $5.16 \pm 0.0321 \mathrm{a}$ \\
NKZ-259 filtrate & $100 \mathrm{a}$ & $5.38 \pm 0.0755 \mathrm{a}$ & $4.59 \pm 0.0451 \mathrm{~b}$ \\
\hline
\end{tabular}

Note: Means with the same letter are not significantly different from each other according to least significant difference (LSD) tests at $p<0.05$ level. Data were recorded and analysed after 1 week 
Table 4 Greenhouse analysis of plant growth promotion by NKZ-259 on tomato plants after 5 weeks

\begin{tabular}{lllll}
\hline Treatment & Root length (cm/plant) & Shoot length (cm/plant) & Fresh weight (g/plant) & Dry weight (g/plant) \\
\hline Water & $5.34 \pm 1.86 \mathrm{~b}$ & $19.53 \pm 3.22 \mathrm{~b}$ & $1.46 \pm 0.61 \mathrm{~b}$ & $0.12 \pm 0.06 \mathrm{~b}$ \\
Medium & $5.98 \pm 1.74 \mathrm{~b}$ & $20.73 \pm 2.05 \mathrm{~b}$ & $1.83 \pm 0.42 \mathrm{~b}$ & $0.18 \pm 0.06 \mathrm{ab}$ \\
Filtrate & $7.50 \pm 1.06 \mathrm{a}$ & $23.13 \pm 1.56 \mathrm{a}$ & $2.56 \pm 0.32 \mathrm{a}$ & $0.24 \pm 0.05 \mathrm{a}$ \\
Culture & $8.08 \pm 1.12 \mathrm{a}$ & $24.20 \pm 2.32 \mathrm{a}$ & $2.63 \pm 0.66 \mathrm{a}$ & $0.25 \pm 0.08 \mathrm{a}$ \\
\hline
\end{tabular}

Note: Means with different letters are significantly different from each other as determined by least significant difference (LSD) tests at $p<0.05$

The PGP bacterium was very stable in the kaolinbased carrier, which may be of significance for agricultural applications. Finally, the results provide strong evidence that Streptomyces fradiae NKZ-259 is a promising and effective PGPR inoculant for plant growth promotion that may enrich soil fertility and enhance crop yields.

\section{Methods}

\section{Collection of Streptomyces fradiae NKZ-259}

NKZ-259 cells were kindly provided by the Functional Genome and Gene Safety Laboratory, Institute of Plant Protection, Chinese Academy of Agricultural Sciences, Beijing, China. This PGP bacterium was collected from soil samples obtained from Qilian Mountain, Qinghai, China, from irrigated but not agricultural land. Sequences have been deposited at GenBank under Accession number CP032266. NKZ-259 was sub-cultured on mannitol soya flour agar (MS) medium containing $20 \mathrm{~g} / \mathrm{L}$ agar, $20 \mathrm{~g} / \mathrm{L}$ mannitol, $20 \mathrm{~g} / \mathrm{L}$ soya flour, and $10 \mathrm{mM} \mathrm{CaCl} 21.109 \mathrm{~g} / \mathrm{L}$ [34] and stored at $4{ }^{\circ} \mathrm{C}$ for future use.
Optimising conditions for IAA production by NKZ-259

For optimum culture conditions, growth medium, IAA production medium, incubation time, carbon and nitrogen sources, and tryptophan concentration were optimised by the OFAT method $[35,36]$. The growth rate of cells was investigated using the conventional oven method [37] to measure dry weight and biomass [38]. Briefly, NKZ-259 cells were grown in various media an after 4 days of incubation they were filtered through a No. 1 Whatman filter paper, dried at $40^{\circ} \mathrm{C}$ for $1 \mathrm{~h}$, and the dry weight of the biomass was measured. Additionally, $\mathrm{pH}$ changes in the culture medium were noted every $24 \mathrm{~h}$ for 2 weeks. In all experiments, the inoculum size was $5.6 \times 10^{6} \mathrm{CFU} / \mathrm{mL}$ of NKZ-259 cells.

IAA production by NKZ-259 was determined using nine different media types; ISP-1, ISP-2, ISP-4, glucoseyeast extract-malt extract (GYM) [39], Bennet's medium, Gause's No.1 medium [40], MS medium, Streptomyces medium [41] and tryptic soy medium [42]. NKZ-259 cells were inoculated in the above media at $28^{\circ} \mathrm{C}$ on a rotary shaker with shaking at $200 \mathrm{rpm}$. After 4 days of

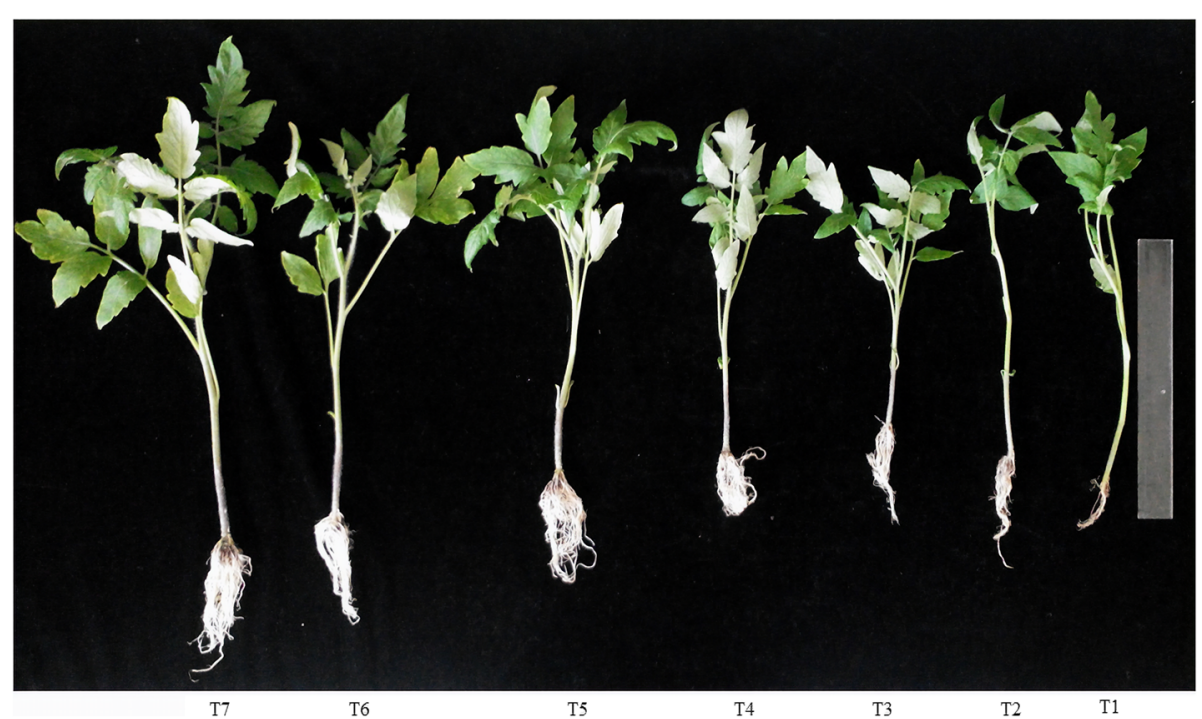

Fig. 6 Effect of different treatments on the growth of tomato plants. $\mathrm{T} 1=$ water, $\mathrm{T} 2=$ kaolin powder without bacterium, $\mathrm{T} 3=$ talc powder without bacterium, $\mathrm{T} 4=$ molasses and humic acid without bacterium, $\mathrm{T} 5=$ talc powder with bacterium, $\mathrm{T} 6=$ molasses and humic acid with bacterium, $\mathrm{T} 7=$ kaolin powder with bacterium 
Table 5 In vivo examination of the plant growth promoting effects of NKZ-259 in different formulations

\begin{tabular}{lllll}
\hline Treatment & Root length $(\mathrm{cm})$ & Shoot length $(\mathrm{cm})$ & Fresh weight $(\mathrm{g})$ & Dry weight $(\mathrm{g})$ \\
\hline T1 & $4.18 \pm 1.12 \mathrm{~d}$ & $27.46 \pm 2.39 \mathrm{bc}$ & $3.87 \pm 1.20 \mathrm{~b}$ & $0.48 \pm 0.33 \mathrm{bc}$ \\
T2 & $5.33 \pm 0.84 \mathrm{~cd}$ & $24.13 \pm 2.13 \mathrm{de}$ & $2.57 \pm 0.54 \mathrm{~b}$ & $0.39 \pm 0.26 \mathrm{c}$ \\
T3 & $5.40 \pm 1.33 \mathrm{~cd}$ & $21.77 \pm 2.52 \mathrm{e}$ & $2.61 \pm 0.71 \mathrm{~b}$ & $0.38 \pm 0.21 \mathrm{c}$ \\
T4 & $5.92 \pm 5.92 \mathrm{bc}$ & $26.00 \pm 1.7 \mathrm{~cd}$ & $3.28 \pm 1.19 \mathrm{~b}$ & $0.32 \pm 0.15 \mathrm{c}$ \\
T5 & $7.13 \pm 1.54 \mathrm{ab}$ & $30.80 \pm 3.46 \mathrm{ab}$ & $6.39 \pm 2.45 \mathrm{a}$ & $0.97 \pm 0.64 \mathrm{ab}$ \\
T6 & $6.92 \pm 0.95 \mathrm{ab}$ & $30.33 \pm 2.99 \mathrm{ab}$ & $6.65 \pm 1.93 \mathrm{a}$ & $1.24 \pm 0.50 \mathrm{a}$ \\
T7 & $7.97 \pm 1.26 \mathrm{a}$ & $32.77 \pm 3.70 \mathrm{a}$ & $6.72 \pm 2.14 \mathrm{a}$ & $1.34 \pm 0.68 \mathrm{a}$ \\
\hline
\end{tabular}

Note: $\mathrm{T} 1=$ water, $\mathrm{T} 2=$ kaolin powder without bacterium, T3 = talc powder without bacterium, T4 = molasses and humic acid without bacterium, T5 = talc powder with bacterium, T6 = molasses and humic acid with bacterium, T7 = kaolin powder with bacterium. Means with different letters are significantly different from each other as determined by least significant difference (LSD) tests at $p<0.05$. These characteristics were measured and calculated after 5 weeks of plant growth

incubation, cells were centrifuged at $12,000 \mathrm{~g}$ for $10 \mathrm{~min}$ and the supernatant was collected. The IAA concentration was measured by colorimetric assay [43] using Salkowski reagent. The pink colour of individual assays was measured using an Infinite 200 Pro NanoQuant UV-vis spectrophotometer (Tecan, Switzerland) at 530 $\mathrm{nm}$. The IAA concentration was also investigated by colorimetric assay using Salkowski reagent. Before optimising, NKZ-259 cells produced $20.46 \mu \mathrm{g} / \mathrm{mL}$ of IAA in Gause's No.1 medium (pH 6.5) containing $20 \mathrm{~g} / \mathrm{L}$ soluble starch, $0.5 \mathrm{~g} / \mathrm{L} \mathrm{NaCl}, 0.01 \mathrm{~g} / \mathrm{L}, \quad \mathrm{FeSO}_{4} \cdot 7 \mathrm{H}_{2} \mathrm{O}, 0.5 \mathrm{~g} / \mathrm{L}$ $\mathrm{K}_{2} \mathrm{HPO}_{4}, 1 \mathrm{~g} / \mathrm{L} \mathrm{KNO}_{3}$ and $0.5 \mathrm{~g} / \mathrm{L} \mathrm{MgSO}_{4} \cdot 7 \mathrm{H}_{2} \mathrm{O}$. To determine the optimum incubation time, IAA production by NKZ-259 was examined at $24 \mathrm{~h}$ intervals for 2 weeks.

For carbon and nitrogen nutrient optimisation, sucrose, glucose, lactose, maltose, mannitol, sorbitol, glycerol and starch were tested as carbon sources, and beef extract, yeast extract, malt extract, soybean flour, casein, tryptone, soy peptone, $\mathrm{KNO}_{3}$ and $\left(\mathrm{NH}_{4}\right)_{2} \mathrm{SO}_{4}$ were tested as nitrogen sources. During optimisation experiments, all other minor nutrients in the medium were kept constant.

Different tryptophan concentrations $(0,1,2,3,4,5,6$, 7, 8, 9 and $10 \mathrm{~g} / \mathrm{L}$ ) were tested for IAA production using a previously described method [44] with some modifications. All experiments were performed in triplicate three times to obtain average values.

\section{Optimising the fermentation medium using the Plackett-}

\section{Burman design (PBD) approach}

After optimising single factors, the Plackett-Burman experimental design was applied to screen variables among the six nutrient factors (soluble starch, $\mathrm{KNO}_{3}, \mathrm{NaCl}$, $\mathrm{K}_{2} \mathrm{HPO}_{4}, \mathrm{MgSO}_{4}$ and $\mathrm{FeSO}_{4}$ ) [45].

Optimisation using the OFAT method suggested that incubation time and tryptophan may be important factors affecting IAA production by NKZ-259, and these parameters were also optimised by the PBD method. Parameters were screened in 12 experiments and the IAA concentration was used as the response value. All variables were evaluated at two widely-spaced intervals, expressed as negative values (low level, -1 ) and positive values (high level, +1). The Minitab 17.0 statistical software package (State College, PA 2010) was used for Plackett-Burman experimental design and analysis of the results.

\section{Response surface methodology using the box-Behnken design}

After optimising process variables by $\mathrm{PBD}$, the most significant six variables (soluble starch, $\mathrm{KNO}_{3}, \mathrm{NaCl}$, $\mathrm{K}_{2} \mathrm{HPO}_{4}$, tryptophan and incubation period) were further subjected to RSM analysis using the Box-Behnken design [46] with the Design-Expert 9.0 statistical software package (Minneapolis, MN, USA).

A set of 54 experiments was generated and each factor was assessed at three levels $(+1,0$ and -1$)$ where 0 is a central coded value, +1 is a high value, and -1 is a low value. These experiments were carried out in triplicate and the average IAA concentration was calculated and taken as the actual response. Predicted response values were also calculated using the regression equation.

Table 6 Evaluation of the suspension rate and wetting time of two wettable powders according to national standards

\begin{tabular}{llll}
\hline No. & $\mathrm{pH}$ & Suspension rate (\%) & Wetting time (second) \\
\hline National standard & - & $\geq 60$ & $\leq 120$ \\
Kaolin powder & $8.10 \pm 0.36 \mathrm{a}$ & $73.74 \pm 6.00 \mathrm{a}$ & $80.0 \pm 6.32 \mathrm{a}$ \\
Talc powder & $8.15 \pm 0.36 \mathrm{a}$ & $50.55 \pm 6.12 \mathrm{~b}$ & $97.2 \pm 14.79 \mathrm{a}$ \\
\hline
\end{tabular}


Table 7 NKZ-259 cell viability rate in different carriers (original cell count in each carrier $=5.6 \times 10^{6} \mathrm{CFU} / \mathrm{mL}$ )

\begin{tabular}{|c|c|c|c|c|}
\hline \multirow[t]{2}{*}{ Carriers } & \multicolumn{4}{|c|}{ Cell population (CFU/mL) } \\
\hline & 1 month & 2 months & 3 months & 4 months \\
\hline Kaolin $\left(4^{\circ} \mathrm{C}\right)$ & $5.4 \pm 0.15 \times 10^{6} \mathrm{a}$ & $5.2 \pm 0.15 \times 10^{6} \mathrm{a}$ & $5.2 \pm 0.15 \times 10^{6} \mathrm{a}$ & $5.2 \pm 0.15 \times 10^{6} \mathrm{a}$ \\
\hline Kaolin (RT) & $5.3 \pm 0.14 \times 10^{6} \mathrm{a}$ & $2.4 \pm 0.15 \times 10^{6} \mathrm{~b}$ & $2.3 \pm 0.2 \times 10^{6} \mathrm{~b}$ & $1.7 \pm 0.2 \times 10^{6} \mathrm{~b}$ \\
\hline Talc $\left(4^{\circ} \mathrm{C}\right)$ & $1.4 \pm 1.15 \times 10^{5} \mathrm{~b}$ & $6.5 \pm 0.20 \times 10^{4} c$ & $5.1 \pm 0.3 \times 10^{4} \mathrm{c}$ & $3.6 \pm 0.25 \times 10^{4} c$ \\
\hline Talc (RT) & $1.0 \pm 0.9 \times 10^{5} \mathrm{~b}$ & $5.5 \pm 0.25 \times 10^{4} \mathrm{c}$ & $5.0 \pm 0.4 \times 10^{4} \mathrm{c}$ & $2.1 \pm 0.2 \times 10^{4} \mathrm{c}$ \\
\hline Liquid $\left(4^{\circ} \mathrm{C}\right)$ & $1.3 \pm 0.15 \times 10^{5} \mathrm{~b}$ & $1.1 \pm 0.11 \times 10^{4} \mathrm{C}$ & $1.2 \pm 0.15 \times 10^{3} \mathrm{c}$ & $0.6 \pm 0.15 \times 10^{3} c$ \\
\hline Liquid (RT) & $1.0 \pm 0.9 \times 10^{5} \mathrm{~b}$ & $1.1 \pm 0.11 \times 10^{4} \mathrm{C}$ & $1.2 \pm 0.2 \times 10^{3} \mathrm{c}$ & $0.4 \pm 0.15 \times 10^{3} \mathrm{c}$ \\
\hline
\end{tabular}

Note: $4^{\circ} \mathrm{C}=$ storage at $4{ }^{\circ} \mathrm{C}$ in a refrigerator; $\mathrm{RT}=$ room temperature storage $\left(27^{\circ} \mathrm{C}\right)$

\section{Extraction, purification and determination of IAA}

NKZ-259 cells were inoculated using the optimum culture conditions, and IAA was separated and purified using a previously reported method [47]. Briefly, NKZ259 cells were incubated in optimised Gause's No.1 medium at $28{ }^{\circ} \mathrm{C}$ with shaking at $200 \mathrm{rpm}$ for 6 days. The fermentation broth was filtered using a Whatman No.1 filter paper and the culture filtrate was adjusted to pH 9 with $1 \mathrm{M} \mathrm{NaOH}$ to keep IAA ionised and more polar. The filtrate was partitioned against $100 \%$ ethyl acetate and the upper organic phase was recovered. The $\mathrm{pH}$ was lowered to 3 with concentrated acetic acid to preserve IAA in the solvent, and the sample was evaporated to dryness. The dried compound was dissolved in $3 \mathrm{ml}$ of analytical grade methanol and used for TLC and HPLC analyses. The IAA standard was prepared at a concentration of $500 \mathrm{ppm}$. Standard IAA and extraction samples were spotted on aluminium-backed silica gel G plates and TLC was performed with a mobile phase of butanone: ethyl acetate: ethanol: water $(3: 5: 1: 1, \mathrm{v} / \mathrm{v} / \mathrm{v} / \mathrm{v})$ [48]. TLC plates were dried and spots were observed under UV light at $256 \mathrm{~nm}$.

The IAA standard and extracted samples were analysed by chromatography on an Agilent 1100 modular HPLC system (Agilent Technologies, Germany). The column temperature was kept at $25^{\circ} \mathrm{C}$. Methanol and $1 \%$ acetic acid $(60: 40 \mathrm{v} / \mathrm{v})$ was used as the mobile phase at a flow rate of $1 \mathrm{~mL} / \mathrm{min}$ [49] and the injection volume was $20 \mu \mathrm{L}$. Detection was monitored at $254 \mathrm{~nm}$ and $280 \mathrm{~nm}$, and data were evaluated using Chem Station Plus.

\section{Assessment of tomato (Solanum lycopersicum L.) germination rate}

Tomato seeds (Qiangfeng 70 White Fruit) were collected from the government compound of Shuanggang town, Jinnan District, Tianjin, China. This is a new variety selected from a single Qingfeng Tomato plant by the Shuanggang Agricultural Technologies Station of Jinnan District, Tianjin, China. In this assay, tomato seeds were firstly disinfected by soaking in $80 \%$ ethanol for $3-5 \mathrm{~min}$, followed by $0.2 \%$ sodium hypochlorite for $3 \mathrm{~min}$, and washed thoroughly with sterilised distilled water three times. Samples were then dried under laminar flow for the next step. Sterilised seeds were soaked in four treatments; (distilled water, Gause's No.1 medium only, NKZ-259 cell suspensions, and the NKZ-259 filtrate) for $2 \mathrm{~h}$. Ten seeds from each treatment (with three replicates) were then placed in a Petri dish containing sterile wet tissue paper and kept under semi-dark conditions at $26 \pm 1{ }^{\circ} \mathrm{C}$ for 1 week, after which time germination rates and shoot and root lengths were measured.

\section{Evaluation of the PGP potential of NKZ-259 on tomato plants under greenhouse conditions}

Firstly, soil, compost and vermiculite were mixed at a ratio of 3:3:1 (pH 6.5) and sterilised by autoclaving at $121{ }^{\circ} \mathrm{C}$ for $30 \mathrm{~min}$ [50]. Tomato seeds were also sterilised using the method described above. The four treatments described above for germination tests were also performed in this assay. For sample preparation, NKZ-259 cells were incubated in Gause's No.1 medium for 6 days to reach a cell density of $5.6 \times 10^{6}$ $\mathrm{CFU} / \mathrm{mL}$. For cell suspension treatments, cells were used without any filtration. For other treatments, the fermentation culture was filtered through a Whatman filter paper and the filtrate was used. For medium treatments, sterilized Gause's No.1 medium was used after autoclaving. After preparing each representative treatment, sterilized seeds were soaked in each treatment for $\sim 2 \mathrm{~h}$ on a rotary shaker at $200 \mathrm{rpm}$ and $28^{\circ} \mathrm{C}$. After treatment, two seeds were transferred to each $20 \mathrm{~cm}$ diameter plastic pot filled with $500 \mathrm{~g}$ of a sterilised soil mixture, and $2 \mathrm{~mL}$ of each bacterial treatment $\left(5.6 \times 10^{6} \mathrm{CFU} / \mathrm{mL}\right)$ was sprayed on each plant once a week. Plants were watered with sterilised distilled water every other day. The experiment was carried out in a greenhouse with a light intensity of $2000 \mathrm{~lx}$ for $16 \mathrm{~h}$ daily at $25 \pm 2{ }^{\circ} \mathrm{C}$. A completely randomised design with ten replicates for each treatment was applied. After 5 weeks, the root length, shoot length, plant height, fresh weight and dry weight of treated plants were measured for each treatment. 
Formulation of NKZ-259 as a plant growth promoter A previous method [51] was modified and applied for wettable talcum powder preparation. The kaolin-based formulation was prepared by mixing $0.3 \%$ sodium alginate (dispersant), $10 \mathrm{~g}$ of starch, $100 \mathrm{~g}$ of kaolin and $0.2 \mathrm{M}$ $\mathrm{CaCO}_{3}$ ( $\mathrm{pH}$ adjustment) and sterilising by autoclaving at $121^{\circ} \mathrm{C}$ for $30 \mathrm{~min}$. After sterilising, $250 \mathrm{ml}$ of cell suspension $\left(5.4 \times 10^{6} \mathrm{CFU} / \mathrm{mL}\right)$ was added and the volume was made up to $500 \mathrm{ml}$ with sterilised water. The wettable powder was then dried at $37^{\circ} \mathrm{C}$ overnight.

For liquid formulation, molasses and humic acid were firstly screened for both cell growth and IAA production. Optimised concentrations of $1 \%$ humic acid $30 \%$ molasses were subsequently used as carriers. Each product was stored at $4{ }^{\circ} \mathrm{C}$ and room temperature in the dark, and the shelf life of NKZ-259 in each product was investigated monthly.

\section{Analysis of plant growth promotion by the formulated products under greenhouse conditions}

Seven treatments (kaolin powder with bacterial strain, talc powder with bacteria, liquid carrier with bacteria, kaolin powder without bacteria, talc powder without bacteria, liquid carrier without bacteria, and sterile distilled water) were evaluated for PGP activity in a completely randomised design with 10 replicates. Tomato seeds were sterilised using the method described above. Two seeds were transferred to each $20 \mathrm{~cm}$ diameter pot containing $500 \mathrm{~g}$ of sterilised soil mixture, $2 \mathrm{~g}$ of each representative sample was completely dissolved in $10 \mathrm{ml}$ of sterilised distilled water, and $2 \mathrm{~mL}$ of each treatment was used to treat plants at weekly intervals. The experiment was carried out in a greenhouse with a light intensity of $2000 \mathrm{~lx}$ and a $16 \mathrm{~h}$ light / $8 \mathrm{~h}$ dark photoperiod with a relative humidity of $75 \%$ at $25 \pm 2{ }^{\circ} \mathrm{C}$. After 5 weeks, various growth characteristics of treated plants including root length, shoot length, plant height, fresh weight and dry weight were measured.

\section{Determination of the suspension rate and wetting time of each carrier}

In accordance with the national wettable powder suspension rate determination standard GB/T 14825-93, 1 $\mathrm{g}$ of each sample was accurately weighed and added to a bottle containing $50 \mathrm{~mL}$ standard hard water, vigorously vibrated and shaken at $120 \mathrm{rpm}$ for $2 \mathrm{~min}$ until uniformly distributed. Samples were then placed in a $30{ }^{\circ} \mathrm{C}$ water bath, and after a 13 min incubation, standard hard water was added to a volume of $250 \mathrm{~mL}$. The bottle was inverted $~ 30$ times per min, the plug was removed, and the bottle was stored vertically in a stable temperature water bath for $30 \mathrm{~min}$. Next, $90 \%$ of the upper suspension was transferred into a beaker and the remaining $10 \%$ was completely removed, dried in an oven at $54{ }^{\circ} \mathrm{C}$, and the suspension rate $(\mathrm{X})$ was calculated according to the formula [32]:

$$
\mathrm{X}=\left(\mathrm{m}_{1}-\mathrm{m}_{2}\right) /\left(\mathrm{m}_{1} \times 10 / 9\right) \times 100 \% .
$$

Where $m_{1}$ is the quantity of the sample $(\mathrm{g})$, and $\mathrm{m}_{2}$ is the quantity of the $10 \%$ residue (g).

The wetting time of each powder was determined as reported by the Chinese pesticide wettable powder wetting time determination standard GB/T 5451-01 [52]. Briefly, a $250 \mathrm{~mL}$ beaker containing $100 \mathrm{~mL}$ standard hard water was placed in the water bath at $25^{\circ} \mathrm{C}$. At that time, the water bath surface and the liquid surface of the sample was the same level. Then, the weighted $1 \mathrm{~g}$ sample was immediately placed into the breaker. The liquid surface was stationary, with no movement, and the wetting time was measured immediately after removing the sample. The experiment was repeated three times and the average value for the wetting time was recorded.

\section{Shelf life analysis of NKZ-259 in each carrier}

The stability of the PGP strain in the carrier is an important factor for commercial production and application. In this case, the viable NKZ-259 cell count in each product was measured after storage at $4{ }^{\circ} \mathrm{C}$ and room temperature using the serial dilution and plate count method at regular intervals, usually once a month.

\section{Analysis of variance (ANOVA)}

A completely randomised design was used throughout the experiment, and data analysis was evaluated by Oneway ANOVA followed by least significant difference (LSD) tests at $p<0.05$ using the Minitab 17.0 statistical software package (State College, PA 2010).

\section{Additional files}

Additional file 1: Table S1. Actual values of process variables in 1000 $\mathrm{mL}$ of fermentation medium. (DOCX $13 \mathrm{~kb}$ )

Additional file 2: Table S2. The Plackett-Burman experimental design. (DOC $37 \mathrm{~kb}$ )

Additional file 3: Table S3. Actual values of process variables in 1000 $\mathrm{mL}$ of fermentation medium. (DOC $29 \mathrm{~kb}$ )

Additional file 4: Table S4. The Box-Behnken experimental design. (DOC $89 \mathrm{~kb}$ )

\section{Acknowledgments}

The authors are very grateful to the Platform of State Key Laboratory of Biology of Plant Diseases and Insect Pests.

\section{Authors' contributions}

EMM performed the experiments and wrote the manuscript. BBG designed the study, analysed the data, and revised the manuscript. JJM analysed the extracted samples by HPLC and helped a lot in this experiment. HLC and $\mathrm{BHL}$ assisted in data analysis and bioinformatics. LMS assisted in greenhouse experiments. MGJ gave some suggestions for powder formulation. KCZ participated in designing the experiment, gave some guidelines and revised the manuscript. All authors read the manuscript and approved it. 


\section{Funding}

This work was supported by grants from the National Key Research and Development Program of China (2017YFD0201301), Central Public-interest Scientific Institution Basal Research Fund (No.Y2017JC12), Talented Young Scientist Program of China (Myanmar-17-03), and Major research project of Guangxi for science and technology (AA18242026). The funds of 2017YFD0201301, Y2017JC12 and AA18242026 assisted with running of the experiments while Myanmar-17-03 provided funding for visiting scholar. The funding organizations only supported funds and did not review or supply any other inputs.

\section{Availability of data and materials}

All data generated or analysed during this study are included in this published article (and its supplementary information files).

\section{Ethics approval and consent to participate}

\section{Not applicable}

\section{Consent for publication}

Not applicable

\section{Competing interests}

The authors declare that they have no competing interests.

\section{Author details}

${ }^{1}$ State Key Laboratory of Biology of Plant Diseases and Insect Pests, Institute of Plant Protection, Chinese Academy of Agricultural Sciences, Beijing, China. ${ }^{2}$ Biotechnology Research Department, Department of Research and Innovation, Ministry of Education, Kyaukse, Myanmar. ${ }^{3}$ Guangxi Key Laboratory of Utilization of Microbial and Botanical Resources, School of Marine Sciences and Biotechnology, Guangxi University for Nationalities, Nanning, China.

Received: 19 January 2019 Accepted: 23 June 2019

Published online: 08 July 2019

\section{References}

1. Karnwal A. Production of indole acetic acid by fluorescent Pseudomonas in the presence of L-tryptophan and rice root exudates. J Plant Pathol. 2009; 91(1):61-3.

2. Boer WD, Folman LB, Summerbell RC, Boddy L. Living in a fungal world: impact of fungi on soil bacterial niche development. FEMS Microbiol Rev. 2005;29(4):795-811.

3. Matsukawa E, Nakagawa $Y$, limura $Y$, Hayakawa M. Stimulatory effect of indole-3-acetic acid on aerial mycelium formation and antibiotic production in Streptomyces spp. Actinomycetologica. 2007;21(1):32-9.

4. Hoster F, Schmitz JE, Daniel R. Enrichment of chitinolytic microorganisms: isolation and characterization of a chitinase exhibiting antifungal activity against phytopathogenic fungi from a novel Streptomyces strain. Appl Microbiol Biot. 2005;66(4):434-42.

5. Crawford DL, Lynch JM, Whipps JM, Ousley MA. Isolation and characterization of actinomycete antagonists of a fungal root pathogen. Appl Environ Microb. 1993;59(11):3899-905.

6. Khamna S, Yokota A, Peberdy JF, Lumyong S. Indole-3-acetic acid production by Streptomyces sp. isolated from some Thai medicinal plant rhizosphere soils. Eurasi J Biosci. 2010;4:23-32.

7. Keyeo F, Ai'shah ON, Amir H. Diazotroph in promoting growth of rice seedlings. Biotechnology. 2011;10(3):267-73.

8. Narayana KJ, Prabhakar P, Vijayalakshmi M, Venkateswarlu Y, Krishna PS. Biological activity of phenylpropionic acid isolated from a terrestrial Streptomycetes. Pol J Microbiol. 2007;56(3):191.

9. Etchells JP, Smit ME, Gaudinier A, Williams CJ, Brady SM. A brief history of the TDIF-PXY signalling module: balancing meristem identity and differentiation during vascular development. New Phytol. 2016;209(2):474-84.

10. Usha MK, Sudhakar P, Sreenivasulu K, Vijayalakshmi M. Optimization of culturing conditions for improved production of bioactive metabolites by Pseudonocardia sp. VUK-10. Mycobiology. 2011;39(3):174-81.

11. Bussamara R, Dall'Agnol L, Schrank A, Fernandes KF, Vainstein MH. Optimal conditions for continuous immobilization of Pseudozyma hubeiensis (strain HB85A) lipase by adsorption in a packed-bed reactor by response surface methodology. Enz Res. 2012;2012:329178.
12. Nor NM, Mohamad R, Foo HL, Rahim RA. Improvement of folate biosynthesis by lactic acid bacteria using response surface methodology. Food Technol Biotech. 2010;48(2):243-50.

13. Hu Y, Qin H, Zhan Z, Dun Y, Zhou Y, Peng N, Ling H, Liang Y, Zhao S. Optimization of Saccharomyces boulardii production in solid-state fermentation with response surface methodology. Biotechnol Biotechnol Equip. 2016;30(1):173-9.

14. Purama RK, Goyal A. Screening and optimization of nutritional factors for higher dextransucrase production by Leuconostocmesenteroides NRRL B-640 using statistical approach. Bioresour Technol. 2008;99(15):7108-14.

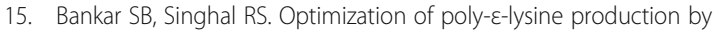
Streptomyces noursei NRRL 5126. Bioresour Technol. 2010;101(21):8370-5.

16. Wani TA, Ahmad A, Zargar S, Khalil NY, Darwish IA. Use of response surface methodology for development of new microwell-based spectrophotometric method for determination of atrovastatin calcium in tablets. Chem Cent J. 2012;6(1):134

17. Bhattacharya SS, Garlapati VK, Banerjee R. Optimization of laccase production using response surface methodology coupled with differential evolution. New Biotechnol. 2011;28(1):31-9.

18. Lumsden R, Lewis J, Fravel D. Formulation and delivery of biocontrol agents for use against soilborne plant pathogens: ACS Publications; 1995.

19. Lumsden R, Lewis J, Fravel D. Formulation and delivery of biocontrol agents for use against soilborne plant pathogens; 1995.

20. Shi L, Nwet TT, Ge B, Zhao W, Liu B, Cui H, Zhang K. Antifungal and plant growth-promoting activities of Streptomyces roseoflavus strain NKZ-259. Biol Control. 2018;125:57-64.

21. Hymavathi M, Sathish T, Brahmaiah P, Prakasham R. Impact of carbon and nitrogen sources on L-asparaginase production by isolated Bacillus circulans (MTCC 8574): application of saturated Plackett-Burman design. Chem Biochem Eng Q. 2010;24(4):473-80.

22. Baş D, Boyacı IH. Modeling and optimization I: usability of response surface methodology. J Food Eng. 2007;78(3):836-45.

23. Kontro $M$, Lignell $U$, Hirvonen MR, Nevalainen A. pH effects on 10 Streptomyces spp. growth and sporulation depend on nutrients. Lett Appl Microbiol. 2005;41(1):32-8.

24. Mirza MS, Ahmad W, Latif F, Haurat J, Bally R, Normand P, Malik KA. Isolation, partial characterization, and the effect of plant growth-promoting bacteria (PGPB) on micro-propagated sugarcane in vitro. Plant Soil. 2001;237(1):47-54.

25. Treichel $H$, de Oliveira D, Mazutti MA, Di Luccio M, Oliveira JV. A review on microbial lipases production. Food Bioprocess Tech. 2010;3(2):182-96.

26. El-Tarabily KA, Sivasithamparam K. Non-streptomycete actinomycetes as biocontrol agents of soil-borne fungal plant pathogens and as plant growth promoters. Soil Biol Biochem. 2006;38(7):1505-20.

27. Spaepen S, Vanderleyden J, Remans R. Indole-3-acetic acid in microbial and microorganism-plant signaling. FEMS Microbiol Rev. 2007;31(4):425-48.

28. Sasirekha B, Shivakumar S. Statistical optimization for improved indole3-acetic acid (IAA) production by Pseudomonas aeruginosa and demonstration of enhanced plant growth promotion. J Soil Sci Plant Nutr. 2012;12(4):863-73.

29. Xie H, Pasternak J, Glick BR. Isolation and characterization of mutants of the plant growth-promoting rhizobacterium Pseudomonas putida GR12-2 that overproduce indoleacetic acid. Curr Microbiol. 1996;32(2):67-71.

30. Khakipour N, Khavazi K, Mojallali H, Pazira E, Asadirahmani H. Production of auxin hormone by fluorescent pseudomonads. Am Eurasian J Agric Environ Sci. 2008:4(6):687-92.

31. Pagnussat GC, Lanteri ML, Lombardo MC, Lamattina L. Nitric oxide mediates the indole acetic acid induction activation of a mitogen-activated protein kinase cascade involved in adventitious root development. Plant Physiol. 2004;135(1):279-86.

32. Cheng $H$, Linling L, Juan $H$, Honghui $Y$, Cheng S. A preliminary preparation of endophytic bacteria CE3 wettable powder for biological control of postharvest diseases. Not Bot Horti Agrobo. 2015;43(1):159-64.

33. Mikkola AM, Shabana AA. A non-incremental finite element procedure for the analysis of large deformation of plates and shells in mechanical system applications. Multibody System Dyn. 2003;9(3):283-309.

34. Hobbs G, Frazer CM, Gardner DC, Cullum JA, Oliver SG. Dispersed growth of Streptomyces in liquid culture. Appl Microbiol Biotechnol. 1989;31(3):272-7.

35. Harikrishnan $H$, Shanmugaiah V, Balasubramanian N. Optimization for production of indole acetic acid (IAA) by plant growth promoting Streptomyces sp VSMGT1014 isolated from rice rhizosphere. Int J Curr Microbiol Appl Sci. 2014;3(8):158-71. 
36. Mohite B. Isolation and characterization of indole acetic acid (IAA) producing bacteria from rhizospheric soil and its effect on plant growth. J Soil Sci Plant Nut. 2013;13(3):638-49.

37. Buono MA, Erickson L. Rapid measurement of Candida utilis dry weight with microwave drying. J Food Prot. 1985;48(11):958-60.

38. Stanbury P, Whitaker A, Hall S. Fermentation economics. In: Principles of fermentation technology, vol. 2; 1995.

39. Martins CS, Souto-Maior AM. Anthracycline production by Streptomyces capoamus in batch fermentation. Braz Arch Biol Technol. 2003;46(3):483-8.

40. Zhou Y, Sun Y-B, He H-W, Feng J-T, Zhang X, Han L-R. Optimization of medium compositions to improve a novel glycoprotein production by Streptomyces kanasenisi ZX01. AMB Express. 2017;7(1):6.

41. Atlas R. In: Parks L, editor. Handbook of microbiological media: CRC Press, Inc; 1993.

42. Arasu MV, Duraipandiyan V, Agastian P, Ignacimuthu S. In vitro antimicrobial activity of Streptomyces spp. ERI-3 isolated from Western Ghats rock soil (India). J J Myco Médical. 2009;19(1):22-8.

43. Bano N, Musarrat J. Characterization of a new Pseudomonas aeruginosa strain NJ-15 as a potential biocontrol agent. Curr Microbiol. 2003;46(5):0324-8.

44. Apine O, Jadhav J. Optimization of medium for indole-3-acetic acid production using Pantoea agglomerans strain PVM. J Appl Microbiol. 2011; 110(5):1235-44.

45. Zhao J, Wang X, Sun W, Mou Y, Peng Y, Zhou L. Medium optimization for palmarumycin $\mathrm{C} 13$ production in liquid culture of endophytic fungus Berkleasmium sp. Dzf12 using response surface methodology. Electron J Biotechnol. 2013;16(6):16.

46. Lanka S, Latha JNL. Response surface methodology as a statistical tool for fermentation media optimization in lipase production by palm oil mill effluent (POME) isolate Emericella nidulans NFCCI 3643. Methodology (RSM). 2015;4(4).

47. Kim Y, Oh YJ, Park WJ. HPLC-based quantification of indole-3-acetic acid in the primary root tip of maize. J Nano Biotech. 2006;3(1):40-5.

48. Ahmad F, Ahmad I, KHAN MS. Indole acetic acid production by the indigenous isolates of Azotobacter and fluorescent Pseudomonas in the presence and absence of tryptophan. Tur J Biol. 2005;29(1):29-34

49. Nakurte I, Keisa A, Rostoks N. Development and validation of a reversedphase liquid chromatography method for the simultaneous determination of indole-3-acetic acid, indole-3-pyruvic acid, and abscisic acid in barley (Hordeum vulgare L.). J Ana Methods Chem. 2012;2012:103575.

50. Anitha A, Rabeeth M. Control of Fusarium wilt of tomato by bioformulation of Streptomyces griseus in greenhouse condition. Afr J Basic Appl Sci. 2009;1:9-14.

51. Sabaratnam S, Traquair JA. Formulation of a Streptomyces biocontrol agent for the suppression of Rhizoctonia damping-off in tomato transplants. Biol Control. 2002;23(3):245-53.

52. Lisansky S, Quinlan R, Tassoni G. Bacillus thuringiensis production handbook: laboratory methods, manufacturing, formulation, quality control, registration: CPL Scientific Ltd; 1993.

\section{Publisher's Note}

Springer Nature remains neutral with regard to jurisdictional claims in published maps and institutional affiliations.

Ready to submit your research? Choose BMC and benefit from:

- fast, convenient online submission

- thorough peer review by experienced researchers in your field

- rapid publication on acceptance

- support for research data, including large and complex data types

- gold Open Access which fosters wider collaboration and increased citations

- maximum visibility for your research: over $100 \mathrm{M}$ website views per year

At BMC, research is always in progress.

Learn more biomedcentral.com/submissions 